\title{
Knowledge processes, knowledge- intensity and innovation: a moderated mediation analysis
}

\author{
Tatiana Andreeva and Aino Kianto
}

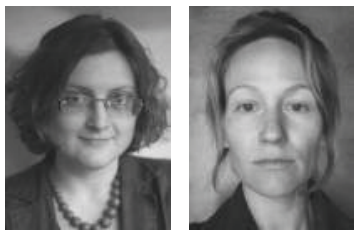

Tatiana Andreeva is an Associate Professor at the Graduate School of Management, St Petersburg State University, St Petersburg, Russia. Aino Kianto is a Professor of Knowledge Management at the School of Business, Lappeenranta University of Technology, Lappeenranta, Finland.
Received June 2011 Revised July 2011 Accepted July 2011

\begin{abstract}
Purpose - The purpose of this paper is to examine innovation from a knowledge-based view by exploring the effect of knowledge processes and knowledge intensity on innovation performance.

Design/methodology/approach - First, a theoretical model of the connections between knowledge processes, knowledge intensity and innovation performance is presented. The posited hypotheses are then tested statistically, using a survey dataset of 221 organizations.

Findings - The result shows that while all knowledge processes have a beneficial impact on innovation, knowledge creation impacts innovation the most and fully mediates the impact of knowledge documentation, intra-organizational knowledge sharing and external knowledge acquisition on innovation performance. Furthermore, knowledge intensity increases all knowledge processes. Knowledge intensity also moderates the relationship of documentation and knowledge sharing with knowledge creation. The interaction effect is negative, meaning that firms in less knowledge-intensive conditions will benefit more from documentation and knowledge sharing for their knowledge creation purposes, and ultimately innovation.
\end{abstract}

Research limitations - The data are limited to companies from Finland, Russia and China.

Practical implications - To promote innovation, managers should pay close attention to knowledge creation processes in organizations. Furthermore, knowledge creation can be facilitated by ensuring efficient documentation procedures, and internal and external knowledge sharing and acquisition practices. Documentation and knowledge sharing are especially effective means to promote knowledge creation for non-knowledge intensive firms.

Originality/value - This paper makes a contribution to the existing literature by building and testing a knowledge-based model of firm innovation and articulating the inter-relations of knowledge processes and knowledge intensity with innovation performance.

Keywords Innovation, Knowledge-based view, Knowledge management, Knowledge processes, Knowledge intensity, Survey, Finland, Russia, China

Paper type Research paper

\section{Introduction}

Innovation has become the quintessential challenge for all types of organizations. A number of economists believe that innovation-based competition can serve as a basis for sustained development in the post-industrial knowledge economy (Romer, 2004). Approached from the knowledge-based perspective, innovation can basically be seen as a process of producing a new viable idea and then implementing it in a way that produces value (Trott, 2005).

The current literature seems to agree that knowledge management can markedly improve innovation in organizations (e.g. Carneiro, 2000; Darroch, 2005; Basadur and Gelade, 2006; Marqués and Simón, 2006; Kianto, 2011). However, the implications of this idea still remain very general (Chapman and Magnusson, 2006). What particular knowledge management 
issues should be prioritized by managers in order to improve innovation performance in their organizations?

Existing literature does not provide a comprehensive answer to this question, and there are several reasons for that. First, most of the earlier studies have either addressed the impact of only one (e.g. Brachos et al., 2007; Deng et al., 2008; Taminiau et al., 2009) or two (e.g. Smith et al., 2005; Chou, 2005) particular knowledge management issues on innovation, or considered all of them in a bulk (e.g. Marqués and Simón, 2006). There have been few previous studies empirically examining the impact of a full range of knowledge processes on innovation (Darroch, 2005; Darroch and McNaughton, 2003). Next, most previous studies on the topic have only considered direct impacts between knowledge processes and innovation and neglected the possibility of more complex mediated relationships. Furthermore, existing research has not considered various contingencies that may influence the interrelationships between knowledge processes and innovation performance.

This paper aims to address these gaps by empirically testing a conceptual model that includes interrelations of four key knowledge processes and innovation, and by examining the mediation between the variables in the model. In addition, the model includes knowledge intensity as contingency variable that has a profound impact on knowledge management and innovation practices. In other words, this paper seeks to inform both knowledge management theory and practice by investigating the following questions: do all key knowledge processes have an equal impact on innovation performance, or are some of them more important? Is there any difference between more knowledge-intensive and less knowledge-intensive firms in the way how knowledge processes influence innovation performance?

To answer these questions, the paper is structured as follows: First, the authors examine innovation from a knowledge-based view and, based on the earlier literature, posit a theoretical model where innovation is seen as the end product of four knowledge-based processes and propose four hypotheses on the interconnections of knowledge processes, knowledge intensity and innovation performance. Next, the research strategy is presented, including data collection methods and sample characteristics. Then the authors turn to the research findings, and finally conclude the paper with a discussion of their theoretical and practitioner implications.

\section{Innovation as a knowledge-based process}

\subsection{Innovation and knowledge management: an overview}

Innovation can be described as the implementation of both discoveries and inventions and the process by which new outcomes, whether products, systems or processes come into being (Williams, 1999). The process definition of innovation - as of a process of interrelated activities from ideas to invention and to its commercialization, where new knowledge is created and used through these activities (Trott, 2005) - highlights that it heavily depends on knowledge. Therefore, it is logical to conclude that knowledge management processes and practices will support innovativeness of an organization.

On the conceptual level, the link between knowledge management and innovation has been widely discussed and accepted (e.g. Pérez-Bustamante, 1999; Carneiro, 2000; Goh, 2005; Basadur and Gelade, 2006, du Plessis, 2007; Xu et al., 2010). For example, Goh (2005) postulates that innovation management should not be seen independently from knowledge management and $\mathrm{Xu}$ et al. (2010) develop a comprehensive conceptual model to demonstrate that various aspects of knowledge management support continuous innovation. A key premise in the literature on new product innovation is that the rate of new product introduction is a function of a firm's ability to manage, maintain, and create knowledge (Cohen and Levinthal, 1990). In their widespread textbook on innovation management, Tidd et al. (2005, p. 15) state that innovation essentially is "about knowledge creating new possibilities through combining new knowledge sets". These conceptual arguments have received some empirical support. Few case studies demonstrate that 
knowledge management systems support innovation (Jang et al., 2002; Suh et al., 2004). Wide-scale, quantitative research in this area is quite scarce, yet it also supports idea about the positive relationship between knowledge management and innovation (Gloet and Terziovski, 2004; Darroch, 2005; Kiessling et al., 2009; Kianto, 2011).

Despite this growing body of literature, there is still lack of a comprehensive model that could integrate various aspects of knowledge management for innovation and thus address practical difficulties in managing knowledge for innovation (Xu et al., 2010). Chapman and Magnusson (2006) claim that the understanding of how to manage knowledge processes in a way that truly contributes to innovation is still limited. They call for more empirical research in this area, in order to move away from a discussion based only on different theoretical assumptions towards a more fine-grained and comprehensive understanding what can be done by knowledge management in practice to improve innovation performance. This paper aims to dwell in this issue further and discuss which elements of knowledge management are most important for innovative results.

\subsection{Knowledge processes as innovation antecedents}

Taking into account close interrelationships between innovation and knowledge, the authors suggest that innovation process can be modeled as an outcome of the knowledge processes in the organization. Indeed, knowledge processes stand out as the key components in achieving successful long-term innovation (Chapman and Magnusson, 2006). The literature typically identifies four to six of such processes (Davenport and Prusak, 1998; Bennett and Gabriel, 1999; Gupta et al., 2000; Parikh, 2001; Bouthillier and Shearer, 2002; Qianwang and Dejie, 2006; Xu et al., 2010) and views them as cyclically interrelated with each other. Though categorizations of the knowledge processes vary, they are still quite similar in their essence and differ mostly by the way or the level of the aggregation. The typically identified knowledge-based processes are knowledge creation, intra-firm knowledge sharing, external knowledge acquisition and knowledge documentation.

Knowledge creation refers to the organization's ability to develop new and useful ideas and solutions regarding various aspects of organizational activities, from products to technological processes to managerial practices (e.g. Nonaka, 1991; Un and Cuervo-Cazurra, 2004). This notion appears to be very close to the one of innovation, and, indeed, these two terms are often used interchangeably. However, there is a subtle difference between them - while knowledge creation refers primarily to the process of development of new ideas, innovation is used in the literature to mean the successfully implemented (and commercialized) outcome of this process, to describe this process, or both (Andreeva, 2009). In this particular paper the authors follow this distinction, using "knowledge creation" to identify the process of development of new knowledge, and innovation - to refer to the results of the successful application of this new knowledge. The authors adopt an overall organizational approach to innovations, viewing them in terms of value-adding renewals in products, processes, work organizational systems or marketing systems of the firm (Weerawardena, 2003; Wang and Ahmed, 2004). Even from the definitions, it logically follows that knowledge creation and innovation are closely interconnected, as creation of the new knowledge provides a basis upon which the innovative actions of all kinds are developed in the organization (Popdiuk and Choo, 2006). For example, Nonaka (1991) reports that companies that score high in knowledge creation, have been also successful in creation of new markets, rapid development of new products, quick response to their customers, and domination in emergent technologies.

Intra-organizational knowledge sharing refers to moving existing knowledge between different organizational actors, both within and between departments and hierarchical levels (Bhatt, 2001; Szulanski, 1996). On the one hand, it helps the company use available resources in the most efficient way by transferring the best practices from one department to another, from one project or client to another, etc. However, the literature suggests that knowledge sharing contributes to creation of new knowledge as well. For example, a closer look at the classical model of organizational knowledge creation by Nonaka (Nonaka, 1991),

PAGE 1018 | JOURNAL OF KNOWLEDGE MANAGEMENT | VOL. 15 NO. 62011 
identifies that knowledge sharing represents the essence of the two out of four stages of the model: the socialization phase includes intensive sharing of tacit knowledge among employees, mainly among close colleagues, while the combination phase concerns sharing explicit knowledge among a broader range of employees through the whole organization (Andreeva, 2009). Cohen and Levinthal (1990) also suggest that knowledge sharing is a critical factor in an organization's ability to respond quickly to change, innovate and achieve competitive success. Kogut and Zander (1992) posit that organizational knowledge creation is dependent on the ability of organization members to exchange and combine existing information, knowledge, and ideas. Brachos et al. (2007) and Taminiau et al. (2009) provide empirical evidence that knowledge sharing positively influences innovations in organizations. Leiponen (2006) also found that in order to contribute positively to innovation performance, knowledge should be made collective - in other words, shared among organizational members.

While knowledge creation and knowledge sharing typically imply intra-firm focus, knowledge acquisition refers to the knowledge that is available outside the firm. Various external sources (from clients and suppliers to competitors and governmental bodies) represent a very rich knowledge source, however, to be able to exploit it organization needs to know how to identify what is interesting and useful in external environment, acquire this knowledge, disseminate it and apply it to commercial end (Cohen and Levinthal, 1990; Zahra and George, 2002). The literature suggests that organizations successful in acquiring external knowledge possess richer and more varied knowledge base, and as a consequence, are more innovative, as innovation is stimulated by the diversity of viewpoints inside the organization and by the richness of its knowledge base (Cohen and Levinthal, 1990; Gulati, 1999; Fabrizio, 2009).

All the knowledge that has been acquired, created and shared, needs to be supported by knowledge storage and documentation, otherwise an organization is constantly in danger of accidentally losing the gained knowledge (e.g. Stein and Swass, 1995). The organizational memory resides in various forms, such as written documents, electronic databases, codified knowledge in expert systems, documented organizational procedures and processes, and tacit knowledge located in individuals (Alavi and Leidner, 2001). Bhatt (2001) highlights that an organization will struggle to retain its competitive advantages, innovativeness, and creativity, if the needed knowledge has not been made easily available in right kind of a format.

\subsection{Innovation as knowledge-based process: development of hypotheses}

The existing literature suggests that knowledge processes are closely interrelated with each other and overall have an impact on organizational innovativeness. However, the literature provides somewhat discrepant and uncoordinated picture of the details of these relationships. For example, Zhou and Uhlaner (2009) present empirical evidence that both external knowledge acquisition and internal knowledge sharing increase innovativeness of the company, while Chang and Lee (2008) and Deng et al. (2008) suggest that it is external knowledge acquisition that contributes to organizational innovation. Powell et al. (1996) and Matusik and Heeley (2005), on the other hand, link external knowledge acquisition not directly to innovativeness, but to firm's capability for knowledge creation. At the same time Chou (2005) demonstrates that knowledge acquisition influences knowledge creation and this link is mediated by knowledge storage capability. Darroch (2005) concludes that knowledge acquisition, knowledge dissemination and responsiveness to knowledge have a positive impact on organizational innovation. Kianto (2011) found a connection between knowledge management activities and continuous innovation. Abou-zeid and Cheng (2004) theoretically propose that some types of innovations would be supported more by knowledge creation processes, while other types of innovations would be supported by knowledge utilization processes. Smith et al. (2005) found that knowledge creation capability of a firm fully mediates the relationship between the potential for intra-firm knowledge sharing and number of innovations in a firm. 
Taken together, the bulk of studies propose a set of divergent, and in some cases, even contradictory interconnections between knowledge processes and innovation. The authors suggest that one of the reasons for these diverse views is that the earlier studies have mostly examined the direct impact of only few particular knowledge management issues. To the best of the authors' knowledge, none of the studies has empirically tested a model including all of the key four knowledge processes and their impact on innovativeness. Furthermore, the previous studies, apart from few exceptions (Smith et al., 2005), only examine the direct impact of knowledge processes, and overlook the possibility of mediated relationships.

However, theoretical support for some mediation interaction might be found in the literature. Indeed, as it was mentioned in the section 2.2, the literature on innovation and knowledge creation typically distinguishes between these two concepts as follows: knowledge creation is about creating a novel idea, while innovation is a successfully implemented and commercialized novel idea (Freeman, 1982; Woodman et al., 1993, Garcia and Galantone, 2002; Andreeva, 2009). Based on these definitions, knowledge creation represents an inherent part of the innovation process. Therefore, considering the set of four knowledge processes, one can imply that knowledge creation is the main knowledge process that influences innovativeness, and other knowledge processes impact innovativeness only through facilitating knowledge creation by providing material for it. Therefore, the literature allows formulating two competing hypotheses: either

H1. Knowledge creation mediates the link between the other knowledge processes and innovation.

or

H2. Each of four knowledge processes - knowledge creation, internal knowledge sharing, external knowledge acquisition and knowledge storage and documentation - has a direct impact on organizational innovativeness.

These two hypotheses reflect the discrepant views in the literature on the relationships between knowledge processes and innovativeness. However, there might be yet another explanation for the discrepant views in the existing literature, namely, the influence of some contextual factors that have an impact on the model. The authors propose that one of such factors that may influence the relationships between different knowledge processes and innovativeness is knowledge intensity of a company's business.

The concept of knowledge intensity reflects the extent to which a firm depends on the knowledge inherent in its activities and outputs as a source of competitive advantage (Autio et al., 2000). Knowledge-intensive organizations are firms whose main activity is based on the employment of knowledge (Starbuck, 1992; Alvesson, 1995; Nurmi, 1998). Moreover, not only their activities are based on knowledge, but also their survival depends on their ability to mobilize and synthesize knowledge (Alvesson, 1995; Nurmi, 1998; Robertson et al., 2003). In other words, knowledge processes are strategic value creation processes for knowledge intensive firms (Larsen, 2001; Lowendahl et al., 2001; Morris and Empson, 1998). Indeed, a lot of sources discuss that knowledge creation (e.g. Larsen, 2001), intra-firm knowledge sharing (e.g. Robertson et al., 2003; Willoughby and Galvin, 2005; Taminiau et al., 2009), external knowledge acquisition (e.g. Bettancourt et al., 2002; Matusik and Heeley, 2005; Evanschitzky et al., 2007; Jenssen and Nybakk, 2009) and knowledge storage and documentation (e.g. Donaldson, 2001; Robertson et al., 2003) are critical for such firms. These facts have two potential implications for this study.

First, one can hypothesize that being the key activity in knowledge intensive organizations, knowledge processes will be more widely present in them as compared with less knowledge-intensive companies. This idea leads to H3a-H3d.

H3a. The more knowledge-intensive a company is, the more intense are its knowledge creation processes.

PAGE 1020 | JOURNAL OF KNOWLEDGE MANAGEMENT | VOL. 15 NO. 62011 
H3b. The more knowledge-intensive a company is, the more intense are its knowledge sharing processes.

H3c. The more knowledge-intensive a company is, the more intense are its knowledge acquisition processes.

H3d. The more knowledge-intensive a company is, the more intense are its knowledge documentation processes.

The second consideration refers to the interrelations between knowledge processes, knowledge intensity and innovation. Based on the strategic importance of knowledge and knowledge processes for knowledge-intensive firms and their critical contribution of performance of such organizations (Alvesson, 1995; Lowendahl et al., 2001), one can hypothesize that

H4a. The more knowledge intensive company is, the stronger is the impact of all knowledge processes towards innovation.

This hypothesis is indirectly supported by the fact that the majority of the studies that discuss the impact of knowledge processes on innovation are based on data from knowledge-intensive firms - e.g. from ICT, biotech, consulting sector, and so on (e.g. Hargadon and Sutton, 1997; Willoughby and Galvin, 2005; Smith et al., 2005; Chaston et al., 2005) - though this is not always acknowledged explicitly. Therefore, most of what is known about the relationships between knowledge management and innovation is actually about knowledge management and innovation in knowledge-intensive businesses. To the best of the authors' knowledge, the question of whether the contribution of knowledge processes to innovation differs between knowledge intensive and non-knowledge intensive firms has not been directly examined in prior empirical studies.

The following section presents the research strategy that was used to examine these hypotheses.

\section{Research methodology}

\subsection{Data collection and sample}

The data were collected with a web-based survey in three countries - Russia, China and Finland. Selecting the countries for analysis, the authors were guided by the following considerations. First, most of the existing empirical papers on knowledge processes and innovation are based on data from one country only (e.g. Gloet and Terziovski, 2004; Darroch, 2005; Marqués and Simón, 2006) and it is not clear whether their findings apply in other economic and social contexts. Second, all of the above mentioned studies are focused on developed countries, therefore, there is still a very little knowledge about the impact of knowledge processes on organizational innovation in developing and emerging economies. To bridge these gaps, the authors decided to choose for this study three very different countries: Finland, China and Russia. These three countries are especially informative and interesting for such comparative research. Finland has been heralded as one of the forerunners in building a sustainable knowledge-based economy and knowledge society, and has recently been either the first or at least in the top three of international competitiveness and educational comparisons. China and Russia are the biggest and growing emerging economies and both have recently put innovation to the forefront of their national development strategy. Therefore, the knowledge management becomes very relevant as it has a potential to support such strategy.

In order to obtain reliable, diverse and comparable data, it was decided to select companies with 50 or more employees that represent both production and service sectors, and industries with different growth rates. The administration of the survey proceeded in several stages and differed slightly among three countries due to differences in business culture and attitudes to surveys. 
As a first step, the pools of companies that fit into the described above criteria were built based on the publicly available databases. The size of the initial pool was 1,264 for Finland and 10,000 in Russia. These pools differed in size as the different response rate was expected across countries. In China such random pool had not been used, due to the reasons described below.

Next, the invitation letters explaining the purpose and the procedure of the research and providing the link to the web-based questionnaire were emailed to the selected companies. Respondents were promised an executive summary report of the research findings as an incentive to complete the survey. In Finland, this was followed by two email reminders, sent one and two weeks after the initial mail. These resulted in 95 responses, or 7.5 percent response rate, that is a rather good result, taking into account significant length of the survey and absence of any informational support from any industry associations or other industry bodies.

In Russia, acknowledging the typical reluctance in the corporate world to participate in any research due to the culture of the information secrecy, it was decided to have a bigger target random pool of companies. The software that was used for administration of this survey allowed tracking the undelivered emails due to the mistakes in the contact information or due to spam filters. It identified that out of 10,000 contacts selected from databases, only 4,064 have actually received the invitation email. This population yielded 145 visits to the survey page (3.6 percent of the population) and 21 responses ( 0.5 percent of the population or 14.5 percent of those who have visited the survey webpage). Taking into account the negative attitudes to this method of data collection in Russia, multiplied by the length of the survey and the novelty of its subject area, this response rate, though being very low, can be considered as good. Further on, to enlarge Russian sample, the invitation to participate in the survey was sent to the members of the alumni club of one of the Russian business schools. This effort yielded a 0.6 percent response rate. In addition, some respondents were also reached through the personal networks of the researchers (with 66 percent response rate). As a result of these efforts, 83 responses were collected.

In China, similarly acknowledging the difficulty of the "cold call" research and importance of personal networking, it was decided not to use random database mailing. The data collection was supported by Knowledge Management Centre of China (KMC), the biggest online KM community of China, which has about 1,000 members from different industries and regions. Additionally, some respondents were reached through the personal networks of the researchers. As a result of these efforts 83 respondents from China filled this questionnaire. Taken into account specifics of the data collection methods, the response rate via online $\mathrm{KM}$ community can be estimated as 5 percent.

As a result of data collection efforts, 261 responses in three countries were collected. Of these, 40 responses were excluded from further analysis as they belonged to the companies under 50 employees. Therefore, the usable sample consisted of 221 responses, quite evenly representing three countries included in the survey (84, or 38 percent Finnish, 64, or 29 percent Russian and 73, or 33 percent Chinese responses). The organizations in the sample represent over 20 industries, with some domination of the production sector over the one of services (63 percent versus 37 percent). The majority of the companies employ between 50 and 500 employees (between 60 percent and 70 percent across three countries). Around 70 percent of the companies in each of the three countries are domestically owned.

The survey reached quite well the management level of the targeted organizations: in Finland and Russia over 70 percent of respondents belonged to middle- or top-management, and in China - over 53 percent. The rest of the surveyed respondents, with minor exceptions, informed that they hold specialist positions in their organizations. While survey questions had been designed in a way that any employee of the organization could answer them, the high share of managerial responses makes the data collected even more insightful. As the survey questions might have required some knowledge of the situation in the organization, the authors controlled for the length of the respondent's service

PAGE 1022 | JOURNAL OF KNOWLEDGE MANAGEMENT | VOL. 15 NO. 62011 
in the organization in discussion. The majority of the respondents (93 percent in Finland and China, and 78 percent in Russia) had worked for their organization for more than one year. Therefore the respondents from the sample provide reliable picture of their organizations.

Taking into account the diversity of the sample that consists of the responses from three very different countries, where a bit different methods have been used to access the organizations, it was necessary to check for the potential differences among the sub-groups in the sample. Differences between correlations and regression equations between the three countries were examined, but no major differences were found.

\subsection{Measures}

There are a number of measures of knowledge processes that are reported in the literature (e.g. Darroch, 2003; Zack et al., 2009; Alavi and Leidner, 2001; Kulkarni and St Louis, 2003; Marqués and Simón, 2006; Mitchell and Boyle, 2010). However, as knowledge management discipline is still in the development phase, various authors model the knowledge processes (both their number and their content) somewhat differently, and commonly accepted operationalizations of these concepts do not exist. Therefore, for the purposes of this research, and with its model in mind, the scales for knowledge processes were combined by the authors based on the literature.

Knowledge creation scale aimed to estimate the frequency of new idea development in the surveyed organizations in different areas of its activities. Some items were borrowed from Kianto (2011), and few more were developed by the research team informed by the literature on knowledge creation (e.g. Nonaka, 1991).

Knowledge storage and documentation was aimed to identify the intensity of storage and documentation of both tacit and explicit knowledge, and also the scope of knowledge repositories in the respondents' organizations. The scale represents the mix of items adopted from Kianto (2011), Karadsheh et al. (2009), and Bayona et al. (2001) and one item was developed by authors based on Alavi and Leidner (2001).

The intra-organizational knowledge sharing scale was developed with the aim to evaluate both vertical and horizontal knowledge sharing within the organization (e.g. Argote and Ingram, 2000, Argote et al., 2000; Szulanski, 1996), and sharing of both tacit and explicit knowledge (e.g. Nonaka, 1991). Few items were extracted from Kianto (2011) and Darroch (2003), and the other ones were developed by the authors informed by the above mentioned literature.

The scale for external knowledge acquisition scale was based on Kianto (2011) and supported by the conceptual literature (Cohen and Levinthal, 1990; Gulati, 1999; Powell et al., 1996). It aimed to provide information on how frequent are knowledge-based interactions of the company with external environment.

A principal component analysis with varimax rotation was conducted to discern dimensions among the variables. To ensure the appropriateness of the explorative factor analysis, normal pre-analysis checks (see Hair et al., 1995) were conducted. The Bartlett test of sphericity demonstrated a highly significant number of correlations in the correlation matrix $(p<0.001)$. Both the Kaiser-Meyer-Oklin measure $(\mathrm{KMO}=0.930)$ and the individual measures of sampling adequacy in the anti-image correlation matrix indicated the suitability of factor analysis.

The principal component analysis yielded a four-factor solution, representing the four knowledge processes, Knowledge documentation and storage, Knowledge sharing, Knowledge acquisition, and Knowledge creation. Composite measures were calculated from the averaged item responses of each construct. Table I presents the items, factor loadings and internal consistencies of the knowledge process variables. The coefficient alphas range from 0.736 to 0.877 , exhibiting a good internal consistency of all the composites. 
Intra-organizational knowledge sharing and application (Cronbach $\alpha=0.877$ )

In our organisation information and knowledge are actively shared within the units

Different units of our organisation actively share information and knowledge

among each other

In our organisation employees and managers exchange a lot of information and knowledge

Our organisation shares a lot of knowledge and information with strategic

partners

Our employees are systematically informed of changes in procedures,

instructions and regulations

$\begin{array}{llll}0.566 & 0.431 & 0.236 & -0.023 \\ 0.602 & 0.373 & 0.366 & -0.016 \\ 0.687 & 0.335 & 0.179 & -0.014 \\ 0.614 & 0.275 & 0.149 & 0.290 \\ 0.690 & 0.230 & 0.353 & 0.145\end{array}$

Knowledge creation (Cronbach $\alpha=0.868$ )

Our organisation frequently comes up with new ideas about our products and/or services

Our organisation frequently comes up with new ideas about our working methods and processes

If a traditional method is not effective anymore our organisation develops a new method

Our organisation uses existing know-how in a creative manner for new

applications

$\begin{array}{llll}0.121 & 0.786 & 0.242 & 0.170 \\ 0.216 & 0.723 & 0.277 & 0.039 \\ 0.334 & 0.734 & 0.187 & 0.123 \\ 0.400 & 0.628 & 0.129 & 0.297\end{array}$

Knowledge storage and documentation (Cronbach $\alpha=0.870$ )

Our organisation does a lot of work to refine, organize and store the knowledge collected

$\begin{array}{llll}0.388 & 0.351 & 0.644 & 0.126 \\ 0.036 & 0.170 & 0.696 & 0.171 \\ 0.145 & 0.248 & 0.832 & 0.203 \\ 0.293 & 0.244 & 0.743 & 0.202\end{array}$

In our organisation we are used to documenting in writing the things that are learnt in practice

In our organization we make sure that the most important experiences gained are documented

$\begin{array}{rrrr}-0.022 & 0.355 & 0.116 & 0.701 \\ 0.149 & 0.053 & 0.310 & 0.659 \\ 0.264 & 0.135 & 0.228 & 0.647\end{array}$

Knowledge acquisition (Cronbach $\alpha=0.736$ )

Our organisation regularly captures knowledge of our competitors

Our organisation regularly captures knowledge obtained from public research institutions including universities and government laboratories

Our organisation regularly captures knowledge obtained from other industry sources such as industrial associations, competitors, clients and suppliers

Note: $(n=221)$

Knowledge intensity was measured with a scale based on Autio et al. (2000). This scale was selected because it is applicable to a wide range of companies across different industries, unlike the more common approaches to measure knowledge intensity R\&D expenditures or number of patents (for discussion see Spender and Grant, 1996; Autio et al., 2000). The exponent alpha for the knowledge intensity composite is 0.733 .

The Innovation performance of the organization was measured based on Weerawardena (2003) by asking the respondents to evaluate the degree of innovations of four different types (products/services, processes, management and marketing) undertaken in the company during the past three years (anchored by "limited" and "extensive"). The coefficient alpha for this composite is 0.738 .

All of the survey items were measured by a six-point semantic differential scale, in order to avoid central tendency bias in responses, with seventh "I don't know" option. Except for the scale of innovation performance, survey items were anchored with "strongly disagree" and "strongly agree".

The initial measures were built in English. In order to ensure that respondents fully understand the questions and to raise the response rate by reaching non-English speaking 
respondents (Harzing, 2000), the survey items were translated into respective languages of the countries in the sample. To secure measurement equivalence, translation procedure followed several iterations, as recommended in the literature on cross-national research (Brislin, 1970; Singh, 1995).

\subsection{Methods of analysis}

As reported above, exploratory factor analysis was performed to check the scales' validity, using SPSS 18.0 software. In order to examine the impact of knowledge processes on innovativeness and check the mediation and moderation effects, regression analysis was used, including Baron and Kenny's (1986) mediated regression technique, as well as moderation regression technique.

\section{Results}

Table II presents descriptive statistics, along with correlation coefficients among all variables $(N=221)$. The posited hypotheses concerning the role of knowledge processes and knowledge-intensity in innovation were first examined by correlational analysis. Table II demonstrates that all study variables are significantly correlated, and all knowledge processes are rather strongly correlated with innovation performance. While knowledge process variables are highly correlated among each other, the principal component analysis reported in Table I above demonstrates their discriminant validity.

To examine the relationship between knowledge processes and innovation, two competing hypotheses were posited. The $\mathrm{H} 1$ stated that knowledge creation mediates the relationship of documentation, knowledge sharing and knowledge acquisition on innovation, while $\mathrm{H} 2$ argued that all four knowledge processes impact innovation performance directly.

The hypothesized mediating effects ( $\mathrm{H}_{1}$ and $\mathrm{H}_{2}$ ) were tested by using the Baron and Kenny's (1986) mediated regression technique. Specifically, they recommend a three-step process:

1. Regressing the mediator variable on the predictor variable (in this study documentation, knowledge sharing and knowledge acquisition on knowledge creation, respectively).

2. Regressing the criterion variable on the predictor variable (e.g. documentation on innovation).

3. Regressing the criterion variable simultaneously on the predictor and mediator variables (e.g. documentation and knowledge creation on innovation).

Results of these three regression equations are then examined to see if they indicate a mediation relationship. Mediation is indicated if the following conditions are met:

1. There is a significant relationship between the mediator and predictor variables (step 1).

2. There is a significant relationship between the predictor and criterion variables (step 2).

3. The mediator is significantly related to the criterion variable (step 3).

Table II Means, standard deviations and correlations between variables

\begin{tabular}{|c|c|c|c|c|c|c|c|}
\hline & Mean & $S D$ & 1 & 2 & 3 & 4 & 5 \\
\hline Innovation performance & 3.60 & 1.08 & 1.00 & & & & \\
\hline Knowledge creation & 3.94 & 1.16 & $0.664^{\star \star \star}$ & 1.00 & & & \\
\hline Documentation and storage & 3.54 & 1.30 & $0.408^{\star \star \star}$ & $0.575^{\star \star \star}$ & 1.00 & & \\
\hline Knowledge sharing & 3.87 & 1.33 & $0.513^{\star \star \star}$ & $0.689^{\star \star \star}$ & $0.623^{\star * *}$ & 1.00 & \\
\hline Knowledge acquisition & 3.70 & 1.18 & $0.313^{\star \star \star}$ & $0.485^{\star \star \star}$ & $0.495^{\star \star *}$ & $0.461^{\star \star \star}$ & 1.00 \\
\hline Knowledge intensity & 4.41 & 1.11 & $0.277^{\star \star \star}$ & $0.407^{\star \star *}$ & $0.202^{\star \star}$ & $0.356^{\star \star \star}$ & $0.158^{\star}$ \\
\hline
\end{tabular}


4. The effect of the predictor on the criterion variable is less in step 3 than in step 2. Full mediation occurs if the effect of the criterion variable becomes non significant in step 3 . Partial mediation occurs if the criterion effect is reduced but significant.

As Table II shows, all composites were highly correlated with each other, which raises the potential problem of multicollinearity concerning regression analyses. Therefore, the variance inflation factors (VIF) were examined. It was found that they were all within acceptable bounds, under the cut-off point of 10 suggested by Hair et al. (1995). Residuals were examined in order to confirm whether there was heteroscedasticity in the regression. No violations of the assumptions of regression analysis were found and so a standard multivariate regression was used to test the hypotheses.

The tests of $\mathrm{H} 1$ and $\mathrm{H} 2$ demonstrated that there is a significant relationship between documentation, knowledge sharing and knowledge acquisition (i.e. the predictors) with knowledge creation (the mediator); and between knowledge creation and innovation (the criterion). For mediation to occur, the impact of documentation, knowledge sharing and knowledge acquisition on innovation have to reduce when the impact of knowledge creation is controlled for.

Table III presents the mediated regressions, which demonstrate that while all knowledge processes impact innovation, knowledge creation fully mediates the impact of documentation, knowledge sharing and knowledge acquisition on innovation. When innovation is regressed simultaneously on the predictor and mediating variables (see Table III, equation 1, step 3), the relationship between documentation and innovation decreased in magnitude (from $\beta=0.439$ to $\beta=0.102$ ), and turns insignificant. According to Baron and Kenny (1986), this suggests a full mediation. The same finding applies to the relationship between knowledge sharing and innovation: the initially significant link between knowledge sharing and innovation $(\beta=0.596)$ becomes nonsignificant $(\beta=0.105)$ when knowledge creation is entered to the equation (equation 2, step 3). Similarily, the relationship between knowledge acquisition and innovation turns insignificant in step 3 (from $\beta=0.345$ to $\beta=0.013$ ). Based on these results, $H 1$ is accepted and $H 2$ is rejected.

H3a-H3d predicted that knowledge intensity impacts all knowledge processes. This assertion was examined by regressing each knowledge process onto knowledge intensity. The results, exhibited in Table IV, demonstrate that knowledge intensity positively impacts documentation, knowledge sharing, knowledge acquisition and knowledge creation. While the impact on documentation and knowledge acquisition is rather small, knowledge intensity explaining 2 percent to 4 percent of their variation, it is statistically significant. On the other hand, knowledge intensity seems to have quite a large impact on knowledge sharing and knowledge creation (12 percent and 16 percent respectively). Thus H3a-H3d are accepted.

Table III Mediating effects of knowledge creation on innovation

\begin{tabular}{|c|c|c|c|c|c|}
\hline Step & Criterion & Predictor & $\beta$ & $\mathrm{t}$ & Adj. $\mathrm{R}^{2}$ \\
\hline 1 & Knowledge creation & Documentation & 0.619 & $11.589^{*}$ & 0.381 \\
\hline 2 & Innovation & Documentation & 0.439 & $7.188^{*}$ & 0.189 \\
\hline 3 & Innovation & $\begin{array}{l}\text { Documentation } \\
\text { Knowledge creation }\end{array}$ & $\begin{array}{l}0.102 \\
0.654\end{array}$ & $\begin{array}{c}1.768 \\
11.307^{\star}\end{array}$ & 0.510 \\
\hline 1 & Knowledge creation & Knowledge sharing & 0.723 & $15.373^{*}$ & 0.520 \\
\hline 2 & Innovation & Knowledge sharing & 0.596 & $10.857^{\star}$ & 0.352 \\
\hline 3 & Innovation & $\begin{array}{l}\text { Knowledge sharing } \\
\text { Knowledge creation }\end{array}$ & $\begin{array}{l}0.105 \\
0.594\end{array}$ & $\begin{array}{l}1.503 \\
8.539^{\star}\end{array}$ & 0.444 \\
\hline 1 & Knowledge creation & Knowledge acquisition & 0.543 & $9.508^{*}$ & 0.292 \\
\hline 2 & Innovation & Knowledge acquisition & 0.345 & $5.404^{\star}$ & 0.115 \\
\hline 3 & Innovation & $\begin{array}{l}\text { Knowledge acquisition } \\
\text { Knowledge creation }\end{array}$ & $\begin{array}{l}0.013 \\
0.703\end{array}$ & $\begin{array}{c}0.239 \\
12.771^{*}\end{array}$ & 0.498 \\
\hline
\end{tabular}

PAGE 1026 | JOURNAL OF KNOWLEDGE MANAGEMENT | VOL. 15 NO. 62011 
Table IV Regression results for knowledge intensity and knowledge processes

\begin{tabular}{|c|c|c|c|c|}
\hline Criterion & Predictor & $\beta$ & $t$ & Adj. $\mathrm{R}^{2}$ \\
\hline Documentation & Knowledge intensity & 0.202 & $3.031^{\star *}$ & 0.036 \\
\hline Knowledge sharing & Knowledge intensity & 0.356 & $5.602^{\star \star \star}$ & 0.123 \\
\hline Knowledge acquisition & Knowledge intensity & 0.158 & $2.358^{*}$ & 0.021 \\
\hline Knowledge creation & Knowledge intensity & 0.407 & $6.554^{\star \star *}$ & 0.161 \\
\hline
\end{tabular}

Finally, H4, which predicted that knowledge intensity moderates the relationship of knowledge processes and innovation, was inspected by running a moderator regression analysis.

In moderated regression analyses, the criterion was regressed to the predictor in the first stage, then the moderator was added in the second stage, and the interactive factor was entered in the third stage. The moderation effect was examined by inspecting the third model. Support for a moderation hypothesis would exist when:

- the results of the model are significant;

- the interaction term is significant in the hypothesized direction; and

- the values for the changes in $R^{2}$ resulting from the introduction of the interaction term and its associated $F$ were significant.

If these conditions are fulfilled, the inclusion of the interaction variable is considered to increase the explanatory power of the model.

Results of the moderator regressions are exhibited in Table V. Concerning documentation, there is a significant interaction between knowledge intensity and documentation $(p<$ 0.001). The negative sign indicates that firms in less knowledge-intensive conditions will benefit more from documentation activities for knowledge creation purposes. The results

Table V Results of the moderator regression analyses

\begin{tabular}{|c|c|c|c|c|c|c|}
\hline Model & Criterion & Predictor & $\beta$ & $t$ & Adj. $\mathrm{R}^{2}$ & Change $\mathrm{R}^{2}$ \\
\hline 1 & Knowledge creation & Documentation & 0.659 & $13.499^{\star \star \star}$ & 0.431 & \\
\hline \multirow[t]{2}{*}{2} & \multirow[t]{2}{*}{ Knowledge creation } & Documentation & 0.626 & $13.058^{\star \star \star}$ & 0.475 & $0.046^{\star \star \star}$ \\
\hline & & Knowledge intensity & 0.217 & $4.531^{\star \star \star}$ & & \\
\hline \multirow[t]{3}{*}{3} & \multirow[t]{3}{*}{ Knowledge creation } & Documentation & 0.994 & $7.480^{\star \star \star}$ & 0.492 & $0.019^{\star \star}$ \\
\hline & & Knowledge intensity & 0.570 & $4.444^{\star \star \star}$ & & \\
\hline & & Knowledge intensity $\times$ Documentation & -0.563 & $-2.957^{\star \star}$ & & \\
\hline 1 & Knowledge creation & Knowledge sharing & 0.747 & $17.303^{\star \star \star}$ & 0.556 & \\
\hline \multirow[t]{2}{*}{2} & \multirow[t]{2}{*}{ Knowledge creation } & Knowledge sharing & 0.715 & $15.994^{\star \star \star}$ & 0.568 & $0.014^{\star \star}$ \\
\hline & & Knowledge intensity & 0.122 & $2.723^{\star \star}$ & & \\
\hline \multirow[t]{3}{*}{3} & \multirow[t]{3}{*}{ Knowledge creation } & Knowledge sharing & 1.037 & $9.328^{\star \star \star}$ & 0.584 & $0.018^{\star *}$ \\
\hline & & Knowledge intensity & 0.496 & $3.918^{\star \star \star}$ & & \\
\hline & & Knowledge sharing $\times$ Knowledge intensity & -0.570 & $-3.151^{\star \star}$ & & \\
\hline 1 & Knowledge creation & Knowledge acquisition & 0.629 & $12.446^{\star \star \star}$ & 0.393 & \\
\hline \multirow[t]{2}{*}{2} & \multirow[t]{2}{*}{ Knowledge creation } & Knowledge acquisition & 0.592 & $11.728^{\star \star \star}$ & 0.429 & $0.039^{\star \star \star}$ \\
\hline & & Knowledge intensity & 0.201 & $3.982^{\star \star \star}$ & & \\
\hline \multirow[t]{3}{*}{3} & \multirow[t]{3}{*}{ Knowledge creation } & Knowledge acquisition & 0.694 & $4.765^{\star \star \star}$ & 0.428 & 0.001 \\
\hline & & Knowledge intensity & 0.298 & $2.149^{\star}$ & & \\
\hline & & Knowledge acquisition $\times$ Knowledge intensity & -0.158 & -0.749 & & \\
\hline 1 & Innovation performance & Knowledge creation & 0.667 & $13.797^{\star \star \star}$ & 0.445 & \\
\hline \multirow[t]{2}{*}{2} & \multirow[t]{2}{*}{ Innovation performance } & Knowledge creation & 0.669 & $12.955^{\star \star \star}$ & 0.441 & 0.000 \\
\hline & & Knowledge intensity & -0.005 & -0.099 & & \\
\hline \multirow[t]{3}{*}{3} & \multirow[t]{3}{*}{ Innovation performance } & Knowledge creation & 0.752 & $6.042^{\star \star \star}$ & 0.440 & 0.000 \\
\hline & & Knowledge intensity & 0.094 & $0.651^{*}$ & & \\
\hline & & Knowledge creation $\times$ Knowledge intensity & -0.152 & -0.735 & & \\
\hline
\end{tabular}


also indicate a significant interaction between knowledge intensity and knowledge sharing $(p<0.01)$. Here also the sign of the beta coefficient is negative, indicating similarly a more pronounced relationship between knowledge sharing and knowledge creation in less knowledge-intensive conditions.

Concerning knowledge acquisition, the interaction with knowledge intensity is non significant, so the incorporation of the interaction term of the degree to which the firm functions in a knowledge-intensive industry and knowledge acquisition does not contribute to improving the explanation of knowledge creation. Similarily, there is no moderation impact of knowledge intensity on the relationship of knowledge creation and innovation.

In sum, knowledge intensity moderates the connection of documentation and knowledge creation, and the connection of knowledge sharing and knowledge creation. However the moderation effect is negative, unlike expected. There is no moderation effect for the relationship of knowledge acquisition and knowledge creation or for the relationship between knowledge creation and innovation. Thus $\mathrm{H} 4$ is rejected.

\section{Conclusions}

In this paper the authors set out to examine innovation as a knowledge-based process. A model of innovation being powered by four types of knowledge processes: knowledge creation, documentation and storage, knowledge sharing and knowledge acquisition was proposed. It was also hypothesized that knowledge-intensity would impact knowledge processes and their relationships with innovation.

The results demonstrated that while all knowledge processes have a beneficial impact on innovation, knowledge creation impacts innovation the most and fully mediates the impact of documentation, knowledge sharing and knowledge acquisition on innovation. Furthermore, knowledge intensity increases all knowledge processes. Knowledge intensity also moderates the relationship of documentation and knowledge sharing with knowledge creation. The interaction effect is negative, meaning that firms in less knowledge-intensive conditions will benefit more from documentation and knowledge sharing for their knowledge creation purposes, and ultimately innovation.

The key contribution of this study is the more specific articulation and empirical examination of relationships between knowledge-related processes and innovation. To achieve this, mediation and moderation effects were examined in addition to direct impacts among the study variables. There is plenty of literature stating the nature of innovation as a knowledge-based process (e.g. Pérez-Bustamante, 1999; Carneiro, 2000; Goh, 2005; Tidd et al., 2005; Basadur and Gelade, 2006, du Plessis, 2007; Xu et al., 2010), and studies that discuss the impact of various knowledge processes on innovation outcomes (e.g. Smith et al., 2005; Darroch, 2005; Chou, 2005; Matusik and Heeley, 2005; Leiponen, 2006; Brachos et al., 2007; Chang and Lee, 2008; Deng et al., 2008; Taminiau et al., 2009). However, these papers tend to focus mostly on one or two knowledge processes, to examine the direct impact of knowledge processes and to overlook the possibility of mediated relationships. In contrast, in this paper the comprehensive model of four knowledge processes was used and the role of knowledge creation as the main knowledge process impacting innovation was clarified. The results demonstrated that the effect of other knowledge processes on innovation is, in fact, mediated by knowledge creation. Thus knowledge creation is the key knowledge process impacting innovation. Activities aimed at documenting and storing organizational knowledge, sharing knowledge in intra-firm interaction, and acquiring knowledge from external sources provide material for knowledge creation processes, where new ideas and approaches are developed, which then can be implemented and commercialized for producing innovations. These findings are in line with some prior research (Matusik and Heeley, 2005). This more complex explanation of the interlinkages of knowledge processes for innovation informs future studies on how to understand these issues.

PAGE 1028 | JOURNAL OF KNOWLEDGE MANAGEMENT | VOL. 15 NO. 62011 
Furthermore, the role of knowledge intensity in knowledge-based innovation has not been previously studied. Interestingly, many of the studies that discuss the relationships between knowledge processes and innovation are based on data from knowledge-intensive firms (e.g. Hargadon and Sutton, 1997; Willoughby and Galvin, 2005; Smith et al., 2005; Chaston et al., 2005), however, current literature does not provide much evidence on whether the findings of such studies would apply to less knowledge intensive sectors. To bridge this gap in current research, both the direct impacts and moderation effects of knowledge intensity on knowledge processes and innovation performance were examined. Here an interesting finding emerged that knowledge intensity negatively moderates the impact of documentation and knowledge sharing on knowledge creation. This again provides a more in-depth understanding of the functioning of knowledge in innovation process.

The somewhat surprising finding can be interpreted in terms of exploitative and explorative knowledge application processes in organizations (March, 1991). Perhaps firms in less knowledge-intensive conditions have to exploit more the explicit (documented) and tacit (made collective by knowledge sharing) knowledge which already exist in their company for knowledge creation purposes, while firms in highly knowledge-intensive conditions should rather explore new knowledge as material for knowledge creation, and therefore not have so much use for already existing knowledge of the firm.

Another potential interpretation of the finding related to the negative impact of knowledge intensity on knowledge documentation might be linked to the scope of application of tacit knowledge in more vs less knowledge intensive environments. To the best of the authors' knowledge, there are no studies that contrasted the amount of tacit vs explicit knowledge used in more or less knowledge intensive businesses, moreover, such study might appear impossible due to the specifics of tacit knowledge (Spender, 1993). However, one can argue that the more intensive usage of and dependence on knowledge would lead consequently to more usage and dependence on its tacit component. As tacit knowledge by its nature cannot be documented, this would logically decrease the usage of documentation in such organizations.

The findings of this study are also of particular interest for the research stream on absorptive capacity. It has been widely accepted within this literature that external knowledge acquisition has a direct impact on organizational innovativeness (Powell et al., 1996; Pittaway et al., 2004; Deng et al., 2008; Chang and Lee, 2008; Fabrizio, 2009). The findings of this study, however, suggest, that this impact is not direct but mediated by knowledge creation process. These results do not undermine the importance of external knowledge acquisition, but they suggest that managers, if they want to sustain the innovativeness in their companies, need to take care not only of knowledge acquisition but of knowledge creation as well. The findings on the moderation effect of knowledge intensity also bear implications for absorptive capacity literature. Indeed, while knowledge acquisition has been frequently portrayed as especially important for knowledge intensive sectors, and many empirical studies on absorptive capacity focused on such industries (e.g. Matusik and Heeley, 2005; Deng et al., 2008; Fabrizio, 2009), the findings from this study suggest that less knowledge intensive sectors benefit from knowledge acquisition equally.

This study also leads to some practical implications. First, its results demonstrate the important role of knowledge processes for innovation. For the practicing managers intending to increase the rate of innovation in their firms, this means that knowledge management is an important activity to master. The managerial lesson from the findings presented above is that, if priorities are to be set, enabling and maintaining knowledge creation process should be the first issue to invest in. In its turn, knowledge creation can be promoted by supporting intra-firm knowledge sharing, external knowledge acquisition, and knowledge documentation. Second, the degree of the knowledge intensity of the company should be considered as an important contingency in the decision making about knowledge management priorities. The findings of this study suggest that for less knowledge intensive firms, knowledge documentation and intra-firm knowledge sharing are especially effective 
ways to increase knowledge creation, and thereby innovation, while for more knowledge intensive firms, also the focus on acquiring external knowledge will significantly pay off.

This study has addressed gaps in previous research on knowledge processes, knowledge intensity and innovations, yet the interpretations proposed are still subject to certain limitations. This study was based on a dataset from three countries: China, Finland and Russia. This means that there were big contextual differences between the observations in the data collected. While it was found that there were no major systematic differences between the different countries in the analysed dataset, the cross-country differences in knowledge-based innovation processes still present a topical research problem. The more specific examination of the country differences in knowledge management should be conducted in further studies, with large datasets from different countries. Larger datasets would also allow testing the proposed comprehensive model with structural equation modelling technique that could allow examining simultaneous interaction among all of the variables in the model. Indeed, findings of this study suggest that mediation and moderation analysis are fruitful avenues for further research that may lead to a better understanding of such complex phenomena as knowledge processes and innovation.

\section{References}

Abou-zeid, E. and Cheng, Q.Z. (2004), "The effectiveness of innovation: a knowledge management approach", International Journal of Innovation Management, Vol. 8 No. 3, pp. 261-74.

Alavi, M. and Leidner, D.E. (2001), "Review: knowledge management and knowledge management systems: conceptual foundations and research issues", MIS Quarterly, Vol. 25 No. 1, pp. 107-36.

Alvesson, M. (1995), Management of Knowledge Intensive Companies, De Gruyter, Berlin and New York, NY.

Andreeva, T. (2009), "Tensions between knowledge creation and knowledge sharing: individual preferences of employees in knowledge-intensive organizations", in Jemielniak, D. and Kociatkiewicz, J. (Eds), Handbook of Research on Knowledge-Intensive Organizations, Hershey, Information Science Reference, New York, NY, pp. 459-76.

Argote, L. and Ingram, P. (2000a), "Knowledge transfer: a basis for competitive advantage in firms", Organizational Behaviour and Human Decision Processes, Vol. 82 No. 1, pp. 150-69.

Argote, L., Ingram, P., Levine, J.M. and Moreland, L. (2000b), "Knowledge transfer in organisations: learning from the experience of others", Organizational Behaviour and Human Decision Processes, Vol. 82 No. 1, pp. 1-8.

Autio, E., Sapienza, H.J. and Almeida, J.G. (2000), "Effects of age at entry, knowledge intensity, and imitability on international growth", Academy of Management Journal, Vol. 43 No. 5, pp. 909-24.

Baron, R.M. and Kenny, D.A. (1986), "The moderator-mediator variable distinction in social psychological research: conceptual, strategic and statistical considerations", Journal of Personality and Social Psychology, Vol. 51 No. 6, pp. 1173-82.

Basadur, M. and Gelade, G.A. (2006), "The role of knowledge management in the innovation process", Creativity and Innovation Management, Vol. 15 No. 1, pp. 45-62.

Bayona, C., Garcia-Marco, T. and Huerta, E. (2001), "Firms' motivations for cooperative R\&D: an empirical analysis of Spanish firms", Research Policy, Vol. 30 No. 8, pp. 1289-307.

Bennett, R. and Gabriel, H. (1999), "Organisational factors and knowledge management within large marketing departments: an empirical study", Journal of Knowledge Management, Vol. 3 No. 3, pp. 212-25.

Bettancourt, L.A., Ostrom, A.L., Brown, S.W. and Roundtree, R.I. (2002), "Client co-production in knowledge-intensive business services", California Management Review, Vol. 44 No. 4, pp. 100-28.

Bhatt, G.D. (2001), "Knowledge management in organizations: examining the interaction between technologies, techniques, and people", Journal of Knowledge Management, Vol. 5 No. 1, pp. 68-75.

Bouthillier, F. and Shearer, K. (2002), "Understanding knowledge management and information management: the need for an empirical perspective", Information Research, Vol. 8 No. 1, paper No. 141. 
Brachos, D., Kostopoulos, K., Soderquist, K.E. and Prastacos, G. (2007), "Knowledge effectiveness, social context and innovation", Journal of Knowledge Management, Vol. 11 No. 5, pp. 31-44.

Brislin, R. (1970), "Back translation for cross-cultural research", Journal of Cross Cultural Psychology, Vol. 1 No. 3, pp. 185-216.

Carneiro, A. (2000), "How does knowledge management influence innovation and competitiveness?", Journal of Knowledge Management, Vol. 4 No. 2, pp. 87-98.

Chang, S.-C. and Lee, M-S. (2008), "The linkage between knowledge accumulation capability and organizational innovation", Journal of Knowledge Management, Vol. 12 No. 1, pp. 3-20.

Chapman, R. and Magnusson, M. (2006), "Continuous innovation, performance and knowledge management: an introduction", Knowledge and Process Management, Vol. 13 No. 3, pp. 129-31.

Chaston, I., Megicks, P. and Williams, J. (2005), "The exploitation of market knowledge within relationship orientated small accountancy practices", Service Industries Journal, Vol. 25 No. 7 , pp. 845-60.

Chou, S.-W. (2005), "Knowledge creation: absorptive capacity, organizational mechanisms, and knowledge storage/retrieval capabilities", Journal of Information Science, Vol. 31 No. 6, pp. 453-65.

Cohen, W.M. and Levinthal, D.A. (1990), "Absorptive capacity: a new perspective on learning and innovation", Administrative Science Quarterly, Vol. 35 No. 1, pp. 128-52.

Darroch, J. (2003), "Developing a measure of knowledge management behaviors and practices", Journal of Knowledge Management, Vol. 7 No. 5, pp. 41-54.

Darroch, J. (2005), "Knowledge management, innovation and firm performance", Journal of Knowledge Management, Vol. 9 No. 3, pp. 101-15.

Darroch, J. and McNaughton, R. (2003), "Beyond market orientation: knowledge management and the innovativeness of New Zealand firms", European Journal of Marketing, Vol. 37 Nos 3/4, pp. 572-93.

Davenport, T.H. and Prusak, L. (1998), Working Knowledge: How Organizations Manage What They Know, Harvard Business Press, Boston, MA.

Deng, X., Doll, W.J. and Cao, M. (2008), "Exploring the absorptive capacity to innovation/productivity link for individual engineers engaged in IT enabled work", Information and Management, Vol. 45 No. 2, pp. 75-87.

Donaldson, L. (2001), "Reflections on knowledge and knowledge-intensive firms", Human Relations, Vol. 54 No. 7 , pp. 955-63.

du Plessis, M. (2007), "The role of knowledge management in innovation", Journal of Knowledge Management, Vol. 11 No. 4, pp. 20-9.

Evanschitzky, H., Ahlert, D., Blaich, G. and Kenning, P. (2007), "Knowledge management in knowledge-intensive service networks: a strategic management approach", Management Decision, Vol. 45 No. 2, pp. 265-83.

Fabrizio, K.R. (2009), "Absorptive capacity and the search for innovation", Research Policy, Vol. 38 No. 2, pp. 255-67.

Freeman, C. (1982), The Economics of Industrial Innovation, Frances Pinter, London.

Garcia, R. and Galantone, R. (2002), "A critical look at the technological innovation typology and innovativeness terminology: a literature review", Journal of Product Innovation Management, Vol. 19 No. 2, pp. 110-32.

Gloet, M. and Terziovski, M. (2004), "Exploring the relationship between knowledge management practices and innovation performance", Journal of Manufacturing Technology Management, Vol. 15 No. 5, pp. 402-9.

Goh, A. (2005), "Harnessing knowledge for innovation: an integrated management framework", Journal of Knowledge Management, Vol. 9 No. 4, pp. 6-18.

Gulati, R. (1999), "Network location and learning: the influence of network resources and firm capabilities on alliance formation", Strategic Management Journal, Vol. 20 No. 5, pp. 397-420.

Gupta, B., Iyer, L.S. and Aronson, J.E. (2000), "Knowledge management: practices and challenges", Industrial Management and Data Systems, Vol. 100 No. 1, pp. 17-21. 
Hair, J.F. Jr., Anderson, R.E., Tatham, R.L. and Black, W.C. (1995), Multivariate Data Analysis with Readings, 4th ed., Prentice Hall, Englewood Cliffs, NJ.

Hargadon, A. and Sutton, R. (1997), "Technology brokering and innovation in a product development firm", Administrative Science Quarterly, Vol. 42 No. 4, pp. 716-49.

Harzing, A. (2000), "Cross-national industrial mail surveys: why do response rates differ between countries?", Industrial Marketing Management, Vol. 29 No. 3, pp. 243-54.

Jang, S., Hong, K., Bock, G.W. and Kim, I. (2002), "Knowledge management and process innovation: the knowledge transformation path in Samsung SDI", Journal of Knowledge Management, Vol. 6 No. 5 , pp. 479-85.

Jenssen, J. and Nybakk, E. (2009), "Inter-organizational innovation promoters in small, knowledge-intensive firms", International Journal of Innovation Management, Vol. 13 No. 3, pp. 441-66.

Karadsheh, L., Mansour, E., Alhawari, S., Azar, G. and El-Bathy, N. (2009), "A theoretical framework for knowledge management process: towards improving knowledge performance", Communications of the IBIMA, Vol. 7, pp. 67-79.

Kianto, A. (2011), "The influence of knowledge management on continuous innovation", International Journal of Technology Management (forthcoming).

Kiessling, T.S., Richey, R.G., Meng, J. and Dabic, M. (2009), "Exploring knowledge management to organizational performance outcomes in a transitional economy", Journal of World Business, Vol. 44 No. 4, pp. 421-33.

Kogut, B. and Zander, U. (1992), "Knowledge of the firm, combinative capabilities, and the replication of technology", Organization Science, Vol. 3 No. 3, pp. 383-97.

Kulkarni, U. and St Louis, R. (2003), "Organizational self assessment of knowledge management maturity", Ninth Americas Conference on Information Systems, available at: http://citeseerx.ist.psu.edu/ viewdoc/download?doi $=10.1 \cdot 1.86 .8010$ andrep $=$ rep1andtype $=p d f($ accessed 28 June 2011).

Larsen, J. (2001), "Knowledge, human resources and social practice: the knowledge-intensive business service firm as a distributed knowledge system", Service Industries Journal, Vol. 21 No. 1, pp. 81-102.

Leiponen, A. (2006), "Managing knowledge for innovation: the case of business-to-business services", Journal of Product Innovation Management, Vol. 23 No. 3, pp. 238-58.

Lowendahl, B., Revang, O. and Fosstenlokken, S. (2001), "Knowledge and value creation in professional service firms: a framework for analysis", Human Relations, Vol. 54 No. 7, pp. 911-31.

March, J.G. (1991), "Exploration and exploitation in organizational learning", Organization Science, Vol. 2 No. 1, pp. 71-87

Marqués, D.P. and Simón, F.J.G. (2006), "The effect of knowledge management practices on firm performance", Journal of Knowledge Management, Vol. 10 No. 3, pp. 143-56.

Matusik, S.F. and Heeley, M.B. (2005), "Absorptive capacity in the software industry: identifying dimensions that affect knowledge and knowledge creation activities", Journal of Management, Vol. 31 No. 4, pp. 549-72.

Mitchell, R. and Boyle, B. (2010), "Knowledge creation measurement methods", Journal of Knowledge Management, Vol. 14 No. 1, pp. 67-82.

Morris, T. and Empson, L. (1998), "Organization and expertise: an exploration of knowledge bases and the management of accounting and consulting firms", Accounting, Organizations and Society, Vol. 23 Nos 5-6, pp. 609-24.

Nonaka, I. (1991), "The knowledge-creating company", Harvard Business Review, Vol. 69 No. 6, pp. 96-104.

Nurmi, R. (1998), "Knowledge-intensive frms", Business Horizons, Vol. 41 No. 3, pp. 26-32.

Parikh, M. (2001), "Knowledge management framework for high-tech research and development", Engineering Management Journal, Vol. 13 No. 3, pp. 27-33.

Pérez-Bustamante, G. (1999), "Knowledge management in agile innovative organisations", Journal of Knowledge Management, Vol. 3 No. 1, pp. 6-17.

PAGE 1032 | JOURNAL OF KNOWLEDGE MANAGEMENT | VOL. 15 NO. 62011 
Pittaway, L., Robertson, M., Munir, K., Denyer, D. and Neely, A. (2004), "Networking and innovation: a systematic review of the evidence", International Journal of Management Reviews, Vol. 5/6 Nos 3-4, pp. 137-68.

Popdiuk, S. and Choo, C.W. (2006), "Innovation and knowledge creation: how are these concepts related?", International Journal of Information Management, Vol. 26 No. 4, pp. 302-12.

Powell, W.W., Koput, K.W. and Smith-Doerr, L. (1996), "Interorganizational collaboration and the locus of innovation: networks of learning in biotechnology", Administrative Science Quarterly, Vol. 41, pp. 116-45.

Qianwang, D. and Dejie, Y. (2006), "An approach to integrating knowledge management into the product development process", Journal of Knowledge Management Practice, Vol. 7 No. 2, available at: www.tlainc.com/articl114.htm (accessed 28 June 2011).

Robertson, M., Scarbrough, H. and Swan, J. (2003), "Knowledge creation in professional service firms: institutional effects", Organization Studies, Vol. 24 No. 6, pp. 831-57.

Romer, P.M. (2004), "The knowledge economy" (Romer, P.M. interviewed by Kurtzman, J.), in Holsapple, C.W. (Ed.), Handbook on Knowledge Management, Springer, Vol. 1 Ch. 5, pp. 73-87.

Singh, J. (1995), "Measurement issues in cross-national research", Journal of International Business Studies, Vol. 26 No. 3, pp. 597-620.

Smith, K.G., Collins, C.J. and Clark, K.D. (2005), "Existing knowledge, knowledge creation capability and the rate of new product introduction in high technology firms", Academy of Management Journal, Vol. 48 No. 2, pp. 346-57.

Spender, J.C. (1993), "Competitive advantage from tacit knowledge? Unpacking the concept and its strategic implications", Academy of Management Best Paper Proceedings, pp. 37-41.

Spender, J.-C. and Grant, R.M. (1996), "Knowledge and the firm: overview", Strategic Management Journal, Vol. 17, pp. 5-9.

Starbuck, W.H. (1992), "Learning by knowledge-intensive firms", Journal of Management Studies, Vol. 3 No. 4, pp. 262-75.

Stein, E.W. and Swass, V. (1995), "Actualizing organizational memory with information systems", Information Systems Research, Vol. 6 No. 2, pp. 85-117.

Suh, W., Sohn, D.J.H. and Kwak, J.Y. (2004), "Knowledge management as enabling RandD innovation in high tech industry: the case of SAIT", Journal of Knowledge Management, Vol. 8 No. 6, pp. 5-15.

Szulanski, G. (1996), "Exploring internal stickiness: impediments to the transfer of best practice within the firm", Strategic Management Journal, Vol. 17, pp. 27-43.

Taminiau, Y., Smit, W. and de Lange, A. (2009), "Innovation in management consulting firms through informal knowledge sharing", Journal of Knowledge Management, Vol. 13 No. 1, pp. 42-55.

Tidd, J., Bessant, J. and Pavitt, K. (2005), Managing Innovation: Integrating Technological, Market and Organizational Change, 3rd ed., Wiley, Chichester.

Trott, P. (2005), Innovation Management and New Product Development, 3rd ed., Pearson Education Limited, New York, NY.

Un, C.A. and Cuervo-Cazurra, A. (2004), "Strategies for knowledge creation in firms", British Journal of Management, Vol. 1 (supplement), pp. 27-41.

Wang, C. and Ahmed, P. (2004), "The development and validation of the organizational innovativeness construct using confirmatory factor analysis", European Journal of Innovation Management, Vol. 7 No. 4 , pp. 303-11.

Weerawardena, J. (2003), "Exploring the role of market learning capability in competitive strategy", European Journal of Marketing, Vol. 37 Nos 3/4, pp. 407-29.

Williams, A. (1999), Creativity, Invention and Innovation, Allen and Unwin, Sydney.

Willoughby, K. and Galvin, P. (2005), "Inter-organizational collaboration, knowledge intensity, and the sources of innovation in the bioscience-technology industries", Knowledge, Technology, and Policy, Vol. 18 No. 3, pp. 56-73.

Woodman, R.W., Savyer, J.E. and Griffin, R.W. (1993), "Toward a theory of organizational creativity", Academy of Management Journal, Vol. 18 No. 2, pp. 293-321. 
Xu, J., Houssin, R., Caillaud, E. and Gardoni, M. (2010), "Macro process of knowledge management for continuous innovation", Journal of Knowledge Management, Vol. 14 No. 4, pp. 573-91.

Zack, M., McKeen, J. and Singh, S. (2009), "Knowledge management and organizational performance: an exploratory survey", Journal of Knowledge Management, Vol. 13 No. 6, pp. 392-409.

Zahra, S.A. and George, G. (2002), "Absorptive capacity: a review reconceptualization, and extension", Academy of Management Review, Vol. 27 No. 2, pp. 185-203.

Zhou, H. and Uhlaner, L.M. (2011), Knowledge Management as a Strategic Tool to Foster Innovativeness of SMEs, ERIM, Report Series Reference ERS-2009-025-ORG, available at: http://ssrn.com/ abstract $=1410468$ (accessed 28 June 2011).

\section{About the authors}

Dr Tatiana Andreeva is an Associate Professor at the Organizational Behavior and Human Resources Management Department, Graduate School of Management, St Petersburg State University, Russia. Her teaching and research are focused on knowledge management, organizational behaviour, change management, and cross-cultural issues in management. Her current research interests include strategic knowledge management and micro-foundations of knowledge management. She has authored and co-authored several academic articles, papers, and book chapters related to these issues. Prior to joining academia, she worked in management consulting in the area of strategy, organizational development and knowledge management. Tatiana Andreeva is the corresponding author and can be contacted at: andreeva@gsom.pu.ru

Dr Aino Kianto is a Professor of Knowledge Management at the School of Business at Lappeenranta University of Technology, Finland. Her teaching and research focus on knowledge management, intellectual capital, creativity, innovation and organizational renewal. Her current interests include the knowledge-based view of the firm and measurement of knowledge-related phenomena in organizations. She has authored and co-authored several academic articles, papers, books and book chapters related to knowledge management, intellectual capital and innovation. In addition to academia, she also has worked with the Future committee of the Finnish parliament and regularly lectures for companies.

To purchase reprints of this article please e-mail: reprints@emeraldinsight.com Or visit our web site for further details: www.emeraldinsight.com/reprints 
This article has been cited by:

1. Ying Liao, Jane Barnes. 2015. Knowledge acquisition and product innovation flexibility in SMEs. Business Process Management Journal 21:6, 1257-1278. [Abstract] [Full Text] [PDF]

2. Fariza Hanim Rusly, Peter Yih-Tong Sun, James L Corner. 2015. Change readiness: creating understanding and capability for the knowledge acquisition process. Journal of Knowledge Management 19:6, 1204-1223. [Abstract] [Full Text] [PDF]

3. Henri Tapio Inkinen, Aino Kianto, Mika Vanhala. 2015. Knowledge management practices and innovation performance in Finland. Baltic Journal of Management 10:4, 432-455. [Abstract] [Full Text] [PDF]

4. Bibliography 291-304. [CrossRef]

5. Stefania Mariano, Christian Walter. 2015. The construct of absorptive capacity in knowledge management and intellectual capital research: content and text analyses. Journal of Knowledge Management 19:2, 372-400. [Abstract] [Full Text] [PDF]

6. Jason F. Cohen, Karen Olsen. 2015. Knowledge management capabilities and firm performance: A test of universalistic, contingency and complementarity perspectives. Expert Systems with Applications 42, 1178-1188. [CrossRef]

7. Anna-Maija Nisula, Aino Kianto. 2015. The role of knowledge management practices in supporting employee capacity for improvisation. The International Journal of Human Resource Management 1. [CrossRef]

8. Banjo Roxas, Martina Battisti, David Deakins. 2014. Learning, innovation and firm performance: knowledge management in small firms. Knowledge Management Research \& Practice 12, 443-453. [CrossRef]

9. Arbaiah Abdul Razak, Peter A. Murray, David Roberts. 2014. Open Innovation in Universities: The Relationship Between Innovation and Commercialisation. Knowledge and Process Management 21:10.1002/kpm.v21.4, 260-269. [CrossRef]

10. Zuher Hamed Al-Omari, Osama Treef Al-Shaki, Mohd Sharifuddin Ahmad, Elsadig Musa Ahmed. 2014. Knowledge Growth Measurement and Formulation for Enhancing Organizational Knowledge Capital. Journal of the Knowledge Economy 5, 616-632. [CrossRef]

11. Fariza Rusly, Peter Yih-Tong Sun, James L. Corner. 2014. The impact of change readiness on the knowledge sharing process for professional service firms. Journal of Knowledge Management 18:4, 687-709. [Abstract] [Full Text] [PDF]

12. Jader Zelaya-Zamora, Dai Senoo. 2013. Synthesizing seeming incompatibilities to foster knowledge creation and innovation. Journal of Knowledge Management 17:1, 106-122. [Abstract] [Full Text] [PDF]

13. Tatiana Andreeva, Aino Kianto. 2012. Does knowledge management really matter? Linking knowledge management practices, competitiveness and economic performance. Journal of Knowledge Management 16:4, 617-636. [Abstract] [Full Text] [PDF]

14. Grzegorz Majewski, Abel Usoro, Peiran SuSimulation of Knowledge Intensive Processes 265-275. [CrossRef]

15. Innovation 200-229. [CrossRef] 